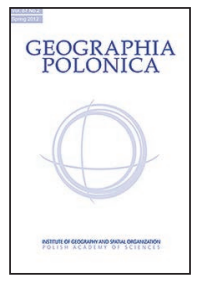

\title{
BORDERSCAPES AND TOURISMSCAPES: THE PLACE OF POSTCARDS IN MEXICAN BORDER TOWN TOURISM
}

\author{
Dallen J. Timothy ${ }^{1,2,3}$ \\ ${ }^{1}$ School of Community Resources and Development \\ Arizona State University \\ 411 N. Central Avenue, Suite 550, 85004, Phoenix, Arizona: USA \\ email: dtimothy@asu.edu \\ ${ }^{2}$ School of Tourism and Hospitality \\ University of Johannesburg \\ Johannesburg: South Africa \\ ${ }^{3}$ College of Tourism \\ Hunan Normal University \\ Changsha: China
}

\begin{abstract}
Since the early 1900s, Mexico's northern border towns became important tourism destinations, receiving more foreign tourists than any other areas of Mexico. Historically, postcards followed the development of tourism in the borderlands, depicting unique border-oriented tourismscapes and life in general, and establishing an iconic image of the border as a rowdy, promiscuous and decadent location where Americans could spend their holidays abroad and participate in tourisms of vice. Until the 2000s, tourism in the US-Mexico border zone was overwhelmingly leisure oriented, and the proliferation of postcards illustrated that fact. Today, there are few postcards left and the ones that do remain are less focused on the border itself, as they once were; instead, they focus on the broader community with less emphasis on the borderline. Changes in border tourism from leisure pursuits to medical tourism and alcohol consumption, growing security concerns, and the proliferation of mobile phones and social media have almost entirely eliminated postcard use as a souvenir and marker of regional tourism identity in the US-Mexico borderlands.
\end{abstract}

\section{Key words}

borders • tourism - postcards - Mexico - United States $・$ landscapes

\section{Introduction}

Although international boundaries have long been barriers to trade and flows of people and products, they have also been intriguing in one form or another for curiosity-seekers. Even highly fortified borders (e.g. North-South Korea, Lebanon-Israel, and the former EastWest Germany) function as significant tourist attractions and are major elements of tours 
in their regions. In this sense, the borderline is the attraction because of the iconic scars it creates on the landscape and because it marks significant differences in political, socio-cultural, and economic systems. To see and feel these differences appeals to human inquisitiveness (Timothy, 1995; Timothy \& Canally, 2008; Gelbman \& Timothy, 2010; Cuevas, Blasco, \& Timothy, 2016; Więckowski, 2018).

Additionally, owing to the unique socioeconomic and political conditions created by borders, the regions and communities adjacent to them (borderlands) have also long held a tourist appeal in most parts of the world. This is especially so when the political divide separates rules of law and economic practices on opposite sides regarding activities that might appeal to leisure visitors, such as drinking, drugs, prostitution, gambling, and shopping. The country with more liberal drinking, prostitution and gaming laws draws visitors, even if for a single day, from neighbouring countries or even further away. Many examples exist throughout the world where contrasting rules and variations in prices, tax rates, and product varieties, draw people to shop, drink, gamble and hire the services of a prostitute - many activities that might be considered illegal or immoral in their home country. These are certainly not the only types of tourism that take place in border regions, for there are many examples of nature-based, cultural heritage, beachfront, and pilgrimagerelated attractions that are located in peripheral regions near international boundaries (Timothy \& Butler, 1995; Paasi \& Raivo, 1998; Timothy, 2001; Gelbman, 2008, 2019; Prokkola, 2010; Więckowski, 2010, 2013; Stoffelen, 2018). However, in most cases it is these former types, particularly those of a decadent nature in many parts of the world, that connect places with activities and create widespread images and reputations.

For these very reasons, since the early twentieth century, most large Mexican towns and villages immediately adjacent to the US border have functioned as important tourist destinations. These cities comprise the southern portions of transfrontier urban agglomerations that are culturally, socially and economically interdependent with their US neighbours. The original appeal of these communities involved the opportunities of vice, particularly prostitution and alcohol consumption which, while somewhat abated from the early years, still continues today (Luna, 2018). As a result, the image of these settlements developed over the decades as rowdy, immoral, filthy places where rules were abandoned and laws went un-enforced (Bowman, 1994; Martínez, 2018). While each Mexican border town has different origins and varying degrees of tourist appeal, what they all have in common is the boundary that separates them from their US neighbours and which created them and their tourist appeal in the first place and sustains their survival.

In common with most other tourist destinations, postcards traditionally played an important role in the Mexican border towns, and since the border created tourism there, it is little wonder that many of the images depicted in the postcards from these communities traditionally have been the border itself (Weigl, 2000; Arreola, 2001, 2017, 2019; Arreola \& Burkhart, 2010; Pearson, 2016). According to Vanderwood and Samponaro (1988), postcards were the medium by which the American public learned about, and created images of, the Mexican border towns in the early twentieth century. They helped to construct popular images of border places before television and personal cameras came into widespread use (Arreola, 2001: 507). Although they were historically an important medium of information about tourism on the border, today, postcard use has diminished, although the cards that do remain depict the border as an important part of life and tourism south of the US-Mexico boundary (Arreola, 2001, 2010).

Against this background, this chapter examines the portrayal of the borderline in tourist postcards from the Mexican side of the US-Mexico border and the role of postcards at the border and asks the following research questions: How is border town 
tourism communicated and images created or maintained through published postcards? What are the present-day general conditions of tourism-oriented border communities that affect the importance of postcards in their tourism industries and their availability for purchase?

\section{Postcards and Tourism}

Postcards have long been one of the most pervasive souvenirs in tourist destinations (Swanson \& Timothy, 2012). They are meant to be mailed from the destination to family members and acquaintances who remain at home, or carried home with the tourists to be placed in photo albums or framed as photographs. In the past, sending a postcard home was part of the excitement of being somewhere different and was frequently enshrined in the ritualization of traveling (Mamiya, 1992; Garrod, 2009).

Postcards satisfy several purposes. They depict elements of life in the place where they originate. Thus, from a traveller's perspective, postcards function as souvenirs or mementos that can bring back happy memories about a favoured vacation experience (Swanson \& Timothy, 2012). Along with postcards come bragging rights about having been somewhere interesting, and as part of a journey's photo documentation, they may be used to show others which localities were visited or activities undertaken during a holiday. From the destination's perspective, postcards may be seen as a marketing tool as they help establish images of places that are handselected to represent the very best elements of the destination. Human (1999: 84) notes that "Postcards represent one of the most pervasive means of creating and sustaining the iconic images of places", a sentiment echoed by other scholars (e.g. Mayes, 2010; Milman, 2011; Symes, 2019; Yüksel \& Akgül, 2007). Thus, having been created by imagemakers, postcards frequently depict overly romanticized and idealized scenes that the destination wishes to convey to the world. In this sense, according to Albers and James
(1988: 136), postcards "formulate and institutionalize what tourists see and how they see it". Thus, like other photographic portrayals, postcard images are easily manipulated to emphasize what the destination wants the outside world to see.

\section{Tourism and the USA-Mexico Border}

The US-Mexico border has always been an area of dynamic change, beginning with its establishment in 1848 following the MexicanAmerican War. After the re-drawing of the border, settlements began to grow adjacent to it in the late 1800s, usually as outposts and customs stations for the Mexican government. In the early 1900 s, a conservative moralist movement began to sweep over the United States, which fought for, and in most cases won, the eradication of gambling and other forms of vice. In response to this movement, the small communities on the southern side of the border saw opportunities to cash in on the changes taking place in the United States. By 1916, entrepreneurs in the Mexican border settlements had established night clubs, liquor shops, bordello bars, and gaming establishments, where all the activities prohibited in the north, such as cock fighting, prostitution, drunkenness, boxing, bullfighting, race track betting, and other forms of gambling drew thousands of Americans across the border for day trips, weekends and even longer vacations, prompting the establishment of hotels, restaurants and other tourism infrastructure (Lucero, 2003).

The US Prohibition law (Volstead Act), which prohibited the manufacture, sale and distribution of alcohol in the United States between 1918 and 1933, added fuel to the southward movement of vice-seeking tourists. Since alcohol was illegal at home, thirsty American visitors flooded into the Mexican border towns, where bars and liquor stores flourished. The entire situation was compounded further with the establishment of US military bases near the border in California, Arizona and Texas, from which lonely soldiers 
poured across the frontier in search of companionship at the brothels and solace at the bars. As a result of these dominant forms of tourism of vice, the Mexican border towns gained a reputation in the United States and elsewhere as unhealthy, unruly, unclean, and somewhat undesirable places for average tourists to visit. Nonetheless, these activities continued to bring money and visitors into the villages, which were typically small, dishevelled, and underdeveloped.

In the 1950s, however, the government of Mexico began considering options to improve the negative image of its border towns. In 1961, in an effort to improve the lives of border residents, to integrate the depressed northern fringe into the national economy, and to clean up the environments and reputations of its frontier towns for tourism and well-being of local residents, the Mexican government launched the National Border Program (PRONAF). This resulted in ports of entry and frontier communities receiving extensive facelifts, including parks, other manicured public spaces, and welcome archways at border crossings (Dillman, 1970). As part of PRONAF, the Border Industrial Program (BIP) was initiated to strengthen the border economy. Under the BIP umbrella, incentives were offered to international companies to establish manufacturing and assembly plants in the Mexican border towns. Several of these plants (maquiladoras) were built in the 1960s, but their growth and prosperity began to proliferate the border towns, particularly Tijuana and Ciudad Juárez, in the 1970s (Hansen, 1982; Prock, 1983). Today there are more than 3,000 maquiladoras in Mexico, employing approximately one million workers (Alam \& Istiak, 2020).

Employment in these foreign-owned plants is an attractive prospect for most Mexicans, as a typical worker can earn approximately \$6-8 USD per day - a significantly higher salary than could be earned doing similar work in other parts of Mexico. Better standards of living and employment potential along the boundary have made the northern border the most prosperous and rapidly growing region of Mexico in economic and demographic terms (Hanson, 1996; Weaver, 2001; Anderson \& Gerber, 2008; Ganster \& Lorey, 2008; Martínez, 2015). This change south of the border, coupled with expanding US-Mexico trade in the past 40 years, has shifted a great deal of economic activity in the United States to its border cities as well, so that a complementary and symbiotic relationship across the border has been created.

Historically, crossing the southern border has been rather easy for Americans, who did not require a passport or visa to cross the frontier in either direction for same-day visits to Mexico. Mexican citizens, on the other hand, have long required a visa to cross into the United States. After the events of September 11, 2001, the situation changed. Border security was strengthened, and in 2009, the US government began requiring American citizens to possess a passport or passport card to re-enter the United States (Fleming, 2014). This initially reduced American crossborder travel, but visitation south of the border stabilised fairly soon thereafter as more US citizens applied for passports.

During the past 15 years, Mexico and its border towns have suffered a great deal of negative publicity owing to the growth of drug cartels and their territorial conflicts, which resulted in well publicised kidnappings, murders and other criminal activity. Likewise, the US-Mexico border has featured prominently in the international media over illegal immigration and the US government's responses to it (Gravelle, 2018). These happenings have reduced the contemporary appeal of the borderlands as a leisure tourist destination, but they remain some of the most visited parts of Mexico (Toudert \& Bringas-Rábago, 2018; Ramos \& Cuamea, 2019), primarily for 'medical tourism' services.

In common with US-Mexico trade and the maquiladora sector, in the realm of tourism, there is also a symbiotic relationship between the two sides of the border (Blasco, Guia, \& Prats, 2014; Cuevas-Contreras \& Zizaldra-Hernández, 2015; Cuevas-Contreras, Zizaldra-Hernández, \& Delgado-Guzmán, 2018). 
The meetings and conventions sector, for instance, benefits considerably from twin cities' border locations. El Paso, for example, hosts many national conventions and meetings owing to the "entertainment value of Juárez" (Weaver, 2001: 112). The same is true of San Diego, which benefits a great deal economically from its proximity to Tijuana. In fact, one of the most popular activities among tourists in San Diego is a day-trip to Tijuana, Mexico (Moker, 2010; Ganster \& Collins, 2017; Arts, 2019).

The improved economic conditions and rapid population growth on the border, coupled with the traditional role of the border as a tourist destination, have made tourism an even more important element of the local economy and international trade. In fact, in the 1980s and 1990s, two thirds of Mexico's entire earnings from tourism originated in the border towns, and the border still plays a huge role in the tourism economy of Mexico with visitors traditionally exceeding by several times the number who visit the country's interior (Curtis \& Arreola, 1989; Gibbons \& Fish, 1987; Frejomil, Sanchez-Crispin, \& Lopez, 1997; Clancy, 2001; Canally \& Timothy, 2007; Timothy \& Canally, 2008).

Today, the primary form of tourism on the US side is shopping, although dining out and visiting relatives are also important in some twin cities. Shopping in the US border towns involves Mexicans typically crossing and returning home the same day to buy household items, furniture, clothing, toys, and other daily necessities that are perceived to be of higher quality or less expensive than at home (Asgary, de los Santos, Vincent, \& Davila, 1997; González \& König, 2016). Large department stores, such as Wal-Mart and Target, as well as supermarkets and grocery stores, are common even in small US towns adjacent to the border, where thousands of Mexicans shop every week in search of bargains. Purchases by Mexicans in US border towns result in billions of dollars in spending and tax earnings for US states and municipalities and more than a million jobs (Sullivan, Bonn, Bhardwaj, \& DuPont, 2012; Fullerton
\& Walke, 2019). Many Mexicans shop in the United States on a weekly or monthly basis, sometimes spending hundreds of dollars each trip. Together with lower prices and product quality, the raised standards of living brought about by maquiladora employment and tourism have allowed many more people to cross the northern border for shopping purposes (Castaño, Perez, \& Quintanilla, 2010).

Tourism on the south side of the border is somewhat different. While Mexican border tourism waned during the First World War and the Great Depression, it picked up again after the Second World War in the same forms that existed in the early twentieth century. In the early 1970s, prostitution was said to be Juárez's main industry, contributing millions of dollars to the city economy (Curtis \& Arreola, 1991). Prostitution today, however, caters more to Mexican nationals, but still exists for foreign visitors as well, albeit at a smaller scale than earlier in the twentieth century (Arreola \& Curtis, 1993; Castillo, Rangel Gomez, \& Delgado, 1999; Shirk \& Webber, 2004; Tiano \& Murphy-Aguilar, 2016).

As noted above, drinking and drug use, perhaps the most copious visitor vice south of the border, grew rapidly in the early twentieth century, and it continues today in the many bars, clubs, and lounges that dot the landscapes of all Mexican border towns of any size. This activity is especially popular among American students who live near the frontier (Lange, Voas, \& Johnson, 2002; Timothy \& Canally 2008; Cherpitel, Ye, Zemore, Bond, \& Borges, 2015). Even young teenagers are sometimes drawn across the border to drink, where rules and age restrictions can be ignored at a glance.

While much of the traditional 'vice' appeal still exists south of the border, new forms of tourism have begun to develop in recent years. Many tourists see the border as a fascinating phenomenon because of its role as a divider of the first world from the third world, and that only a few steps away, one can see a completely different way of life (Curtis \& Arreola, 1989; Timothy \& Canally, 2008). 
This contrast between rich and poor, developed and underdeveloped, is a major draw. In the context of the US-Mexico border, Curtis (1993: 56) notes, "The built environment and the genius loci leave little doubt that Nuevo Laredo lies in the third world and Laredo does not". Likewise, in recent years, with the rise in health care and pharmaceutical costs in the United States, many Americans now travel south of the border to receive medical and dental care, and to buy prescription drugs for a fraction of what they cost at home (Oberle \& Arreola, 2004; Turner 2008, Martínez Almanza, Guía Julve, Morales Muñoz, \& Esparza Santillana, 2019). Shopping for souvenirs and other curios remains an important component of tourism south of the border but now takes a distant second place to health care consumption (Cuevas, Blasco, \& Timothy, 2016).

Regardless of the activities undertaken, estimates suggest that the majority of visitors to Mexican border towns are day-trippers who generally stay less than six hours in the larger cities and four hours in the smaller towns. Most visitors are residents of US border states and 'snowbirds' (seasonal residents from the northern states and Canada), followed by other tourists from Canada, Western Europe and other regions of the world (Arreola \& Curtis, 1993; Arts, 2019). The Mexican border communities are popular destinations for domestic tourists as well, owing to their historic role in the Mexican Revolution, their high levels of economic development compared to the rest of the country, strong familial relationships with border residents, and their proximity to the United States, which can be visited if the visitors are able to obtain visas.

All of the main Mexican border towns possess tourist districts either adjacent to the port of entry or within easy walking distance $(1-2 \mathrm{~km})$. The landscapes of the tourist districts today are plastered with liquor stores, bars and restaurants, dental and medical offices, pharmacies, souvenir and craft shops, and apparel and jewellery outlets. The districts' location near the border reflects visitors' propensity to want to stay close to the United States and not venture too far into 'uncharted' territory.

Although many foreign visitors travel to the border towns by bus, train and airplane, the majority drive to the border, park in the United States, and walk across to the nearby tourist districts to shop, visit health care services, drink or search for other exotic diversions (Arreola \& Madsen, 1999; Timothy \& Canally, 2008; Cuevas, Blasco \& Timothy, 2016).

Like most other tourist destinations, border regions have long issued postcards for tourist use. In border areas, postcard images depict a wide range of natural and cultural elements, but of particular interest to the specific borderland context is the representation of borders and border-related phenomena (Milman 2012; Arreola, 2013).

\section{Data Sources}

As already noted, this chapter examines postcards in Mexican border communities. The fieldwork and card collection took place during multiple visits in the border cities of Tijuana, Baja California (pop. 2.1 million); Nogales, Sonora (pop. 220,000); and Ciudad Juárez, Chihuahua (pop. 2.5 million), between 2005 and 2010 (Fig. 1). Follow-up site visits were also undertaken in 2018-2019 to the same cities to examine any changes that might have taken place and to check on the current availability of postcards. During this time period, no new postcards had been produced. These cities were selected because they are the most popular Mexican border towns for tourism south of the US border states of California, Arizona and Texas. There are no large Mexican cities south of New Mexico. Likewise, these three cities are located near large market populations (San Diego and Los Angeles; Phoenix and Tucson; and El Paso) with the most developed tourist zones (Arreola \& Curtis, 1993; Canally \& Timothy, 2007).

The information presented in this chapter comes from two primary sources: postcard analysis and observations. The original plan 


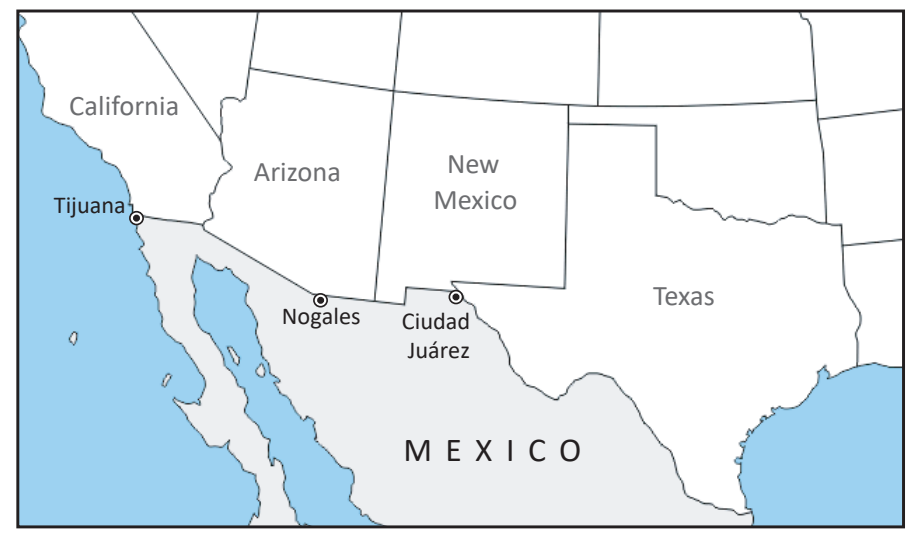

Figure 1. Locations of study cities on the US-Mexico border

was to examine postcards from both sides of the border, but after considerable searching and speaking with shopkeepers on the US side, the decision was made only to focus on the Mexican towns, because there were no comparative cards in the US border towns. No postcards were found in Nogales, Arizona, San Ysidro/San Diego, California, or in the region of El Paso adjacent to the border. Four types of postcards were found by the author at the El Paso airport but were not included in this analysis. Postcard availability will be discussed later as part of the findings. On the Mexican side, every curio shop, pharmacy and liquor store in the tourist districts of all three cities was visited for the purpose of buying postcards for analysis. Only 98 different postcards were identified together in all three cities during the period described above - 51 in Tijuana, 23 in Nogales, and 24 in Ciudad Juárez. One copy of each postcard was purchased and filed for analysis.

There is a vast and growing tourism literature based on analyses of visual imagery (e.g. Markwick, 2001; Jenkins, 2003; Edelheim, 2007; Garrod, 2009; Milman 2011, 2012; Garrod \& Kosowska, 2012). This study utilizes the same method used by most researchers, namely thematic content analysis. The postcards were examined on two separate occasions by the author and a research assistant through the process of familiarization, inventory, analysis and tabulation (Collier \& Collier,
1999). During the familiarization phase, the images were categorized individually and then by consensus into heuristic focal themes, which were subsequently used to explore the images further through inventory and content analysis to find patterns of frequency and clustering (Albers \& James, 1988).

Observations and first-hand experience from field visits and dozens of previous and later visits to all three cities produced valuable information about visitor behaviour, the venues where postcards could be purchased, the types of postcards available, and various other aspects of tourism in each community, particularly in relation to the border. The findings from this research are presented in the sections that follow.

\section{Postcards from the Border}

Arreola (2001, 2010, 2013, 2017, 2019) has examined at great length the historical development of postcard images from the USMexico border. His collection, in fact, consists of thousands of individual postcards from the Mexican border towns from the early 1900s until the 1990s. His examination of historical postcards from Nogales, Mexico, reveals some interesting patterns (see Tab. 1). It is obvious that throughout the twentieth centu$r y$, the borderline itself and the ports of entry (border gates) were an important component of the appeal of border towns, at least 
as reflected in the 62 postcards that depict these images. In the Nogales context, only street scenes (64) appeared in more of Arreola's postcards. To a lesser extent, other public spaces (plazas and residential areas) (31), panoramic views (27), and public buildings and monuments (25) were popularly depicted as well. Arreola's work also demonstrates that the border and its various views (entry gates, the borderline and fence, etc) on postcards have decreased through time in relation to other emerging themes (e.g. historic monuments and aerial panoramas).

Table 2 presents the frequencies of postcard images from the three border cities under examination in this study. As the table demonstrates, the most common images portrayed in the Nogales, Ciudad Juárez and Tijuana postcards are of historic monuments and buildings. Most of the images in this category reflected monuments commemorating famous Mexican heroes, such as Benito Juárez and the Aztec warrior Cuahutémoc, and in the case of one card from Tijuana, a statue of the famous American president Abraham Lincoln. Other monuments commemorate the Mexican Revolution and the nation's cultural diversity. Museums are another important image portrayed on the postcards from Juárez and Tijuana. One Juárez picture portrays a former customs station that now houses a municipal museum. Spanish colonial cathedrals were also the focus of several cards from Tijuana and Ciudad Juárez. In common with the former customs station, the cathedrals, besides symbols of community and culture, are indicative of a frontier situation, as the towns were considered marginal outposts of Spain (and later, Mexico) and were locations where Mexican sovereignty could be asserted and exercised.

Interestingly, the second most common images were those of cities outside the communities where they were being sold. This primarily entailed postcards reflecting panoramic shots, street scenes, parks and historic sites from cities in the same state (i.e. the capitals) but often a considerable distance from the place itself. For instance, several postcards were being sold in Nogales that depicted scenes from Hermosillo, the state capital of Sonora $250 \mathrm{~km}$ away. Likewise, Tijuana shops sold images from Ensenada, a popular tourist destination to the south. Even three postcards from the United States (e.g. Tucson and Phoenix) were being offered in Nogales at two different shops, thereby establishing yet another linkage with the border.

The street scenes inevitably illustrate the crowded conditions of the border towns' tourist zones - tourists, vendors, residents, and vehicular traffic. Souvenir vendors, shops, pharmacies, bars, and restaurants are typically the focus of the street scenes, which appear to be portrayed as a way of demonstrating the array of retail establishments, to attract visitors to the many shopping, drinking and eating opportunities.

While some of the aerial shots show only the Mexican side of the border, the majority (15) show both sides of the border, and include text of a nature that highlights the bi-national nature of the cities (e.g. Nogales, Sonora/Nogales, Arizona). Most of the pictures in this category focus on the central urban cores, usually including the tourist districts, CBDs, and in most cases the borderline itself becomes the central focus of the image as it bisects the conurbations.

Arreola's (2001: 509) analysis noted that the gate crossings traditionally have been the most popular postcard views sold in Nogales. In fact, according to his collection, they totaled nearly a quarter of all Nogales postcard images. In the sample collected for this study, this was not the case any longer. Four of the 23 Nogales postcards (17.4\%) depict the border fence/gateway; in Tijuana, ten percent depict the border crossing. Only two postcards from Juárez depict the main international bridge. Arreola (2001) provides some insight into the reasons for the change in focus from the borderline itself to other urban scenes. In the context of Nogales, he noted,

"The first fence dividing a Mexican from an American border town was erected 
Table 1. Historical Nogales postcards by view depicted

\begin{tabular}{|l|c|}
\hline \multicolumn{1}{|c|}{ View } & Frequency \\
\hline Streetscapes & 64 \\
The border itself (fences, gateways and markers) & 62 \\
Panoramas & 27 \\
Public buildings and monuments & 25 \\
La Caverna (famous underground restaurant) & 20 \\
Plazas & 20 \\
Bullfights & 12 \\
Residential areas & 11 \\
Miscellaneous & 21 \\
\hline
\end{tabular}

Source: adapted from Arreola (2001).

Table 2. Frequencies of postcard images ${ }^{\star}$ in Mexican border towns, 2005-2019

\begin{tabular}{|l|c|c|c|c|}
\hline \multicolumn{1}{|c|}{ View } & Juárez & Nogales & Tijuana & Total \\
\hline Aerial panoramas & 4 & 5 & 6 & 15 \\
International bridge & 2 & 0 & 0 & 2 \\
Border gateway/port of entry & 0 & 4 & 5 & 9 \\
Street scenes & 1 & 1 & 17 & 19 \\
Markets & 3 & 0 & 0 & 3 \\
Historic sites/monuments/buildings & 4 & 5 & 14 & 23 \\
Cultural and tourist activities & 1 & 0 & 6 & 7 \\
Cards from other cities/states & 9 & 8 & 3 & 20 \\
\hline Totals & 24 & 23 & 51 & 98 \\
\hline
\end{tabular}

Source: author's analysis.

* Several of the cards had split/multiple images. In this case, the most frequently depicted category was counted.

in Nogales. Gate crossings evolved as official ports of entry along a declared buffer zone between the Sonora and Arizona towns. These landscapes became photographed as postcard views when Ambos Nogales began being promoted as a tourist destination. The fence line and gate crossings were fixed features of border-town identity by the early twentieth century" (Arreola, 2001: 509).

Today, however, the city has more to offer than just the border. Arreola suggests that postcards are no longer the dominant medium for recording the border towns, and the nature of border town tourism has changed. While Nogales, Sonora, attracts approximately a million foreign visitors annually, the tourist orientation has changed since the early years. According to one local official, the vast majority of visitors are day-trippers who make international excursions of less than a few hours rather than the overnight visits that dominated border town tourism earlier in the twentieth century. Likewise, these day visitors now utilize their mobile phones to take their own photographs rather than depending on postcards to capture local images.

"The combination of shorter, more frequent visits with a general decline in traditional forms of correspondence like postcards means that postcard views have less credibility for travelers than they did in the past. Besides, many of the excursionists to Ambos 
Nogales today bring their own cameras and snap away at a myriad of views to capture their own images" (Arreola, 2001: 510).

The cultural and tourist activity postcards depict people wearing sombreros and serapes, dancers performing for tourists, and stereotypical border town tourist activities, such as people sitting on donkeys that are painted to look like zebras, donning flowered sombreros and draped with serapes. Images like these have come to dominate the landscape of the border town tourist districts and are usually contrived to appear as stereotypically touristified as possible. The staged nature of the zebra burros, particularly as depicted in postcards, cogently resembles what Weigl (2000: 56) calls the stereotyped Mexico, which casts the Mexican people as "an exotic other". Most postcards, Weigl (2000: 56) argues, frame Mexicans "in a stereotypical manner as sombrero-clad, burro-riders (...) it is obvious that stereotypes of Mexicans are still a vital part of the visual vocabulary and concept of Mexico as (...) consumed by US society".

To Curtis and Arreola (1989: 20), the border tourist districts represented in postcards are "illusionary, anachronistic places where merchants cater to tourists' expectations by marketing a vision of Mexico that is a product of history, myth, reality and fantasy". They also suggest that tourists like to cross the border because there they find "an idealized 'Mexicoland' that is somewhat insulated from the real world and danger but one that evokes at least a veiled sense of excitement and foreign adventure" (Curtis \& Arreola, 1989: 23). Herzog (2003: 127) concurs and muses that,

"Revolution Avenue is to Tijuana what Main Street, U.S.A. is to Disneyland - an artificial promenade that sets the mood for a carefully choreographed experience. In Disneyland, visitors park their cars and walk across the parking lot, through the entrance gates, and onto Main Street, a theatrical stage set, built at 4/5 scale, and lined with costumed characters, from Mickey Mouse to a Barbershop Quartet. In Tijuana, tourists park their cars in vast lots just north of the border, cross the pedestrian entrance into Mexico, and move along a path that leads them to Revolution Avenue. Revolution Avenue is a mini-theme park - a clever stage set of outrageous color and grotesque facades. Buildings resemble zebras or Moorish castles. Flags and colorful blimps fly overhead. Music blares, whistles blow, barkers shout along its entire one mile length. The setting is a classic 'other directed space', a vacation-land and consumer haven created for outsiders.".

These images are also important because the US-Mexico border is essentially the only place in the world where first world meets third world at such a stark and narrow divide. For many tourists, the obvious differences in economic, cultural and political systems, which can be felt immediately at the boundary (quite literally), adds intrigue to the tourist ambience. This condition gives rise and lends importance to the stereotyped images at the border, because as Morgan and Pritchard (1998: 242) note, images of the developing world usually reflect a western, white, colonial bias in which the "dynamic First World contrasts itself with a static, timeless and unchanging Third World".

Only three postcards from Juárez depicted outside and inside views of Pueblito Mexicano (a shopping centre decorated as a small Mexican town) and Mercado Juárez, the main market, with an array of shops and crowds of people. Their being featured is likely a result of the importance of the Mercado and the Pueblito in the city's tourism product mix. The Pueblito also houses a small museum and restaurant.

\section{The situation today}

As the previous section illustrates, postcards have long been an important medium for depicting tourism activities and the prominence of the borderline in the Mexican border towns. Earlier in the twentieth century, postcards played a crucial part in the growth of border tourism and assisted in bringing 
about the Mexican border towns' widespread notoriety among North Americans and Europeans (Arreola, 2001, 2017, 2019; Arreola \& Burkhart, 2010; Vaquera-Vásques, 2012). Today, however, the importance of postcards as an information medium and marker of place-based experience has diminished considerably for two primary reasons. First, the nature of tourism in the border towns has changed considerably. Rather than the traditional leisure-oriented product of yesteryear, the 21st-century visitor experience at Mexico's northern frontier is dominated by pharmacy runs, medical treatments, and alcohol purchases. Thus, there is significantly less motivation to buy and send postcards - traditionally viewed as a leisure activity - from utilitarian spaces and during utilitarian times. Likewise, the security situation in the Mexican borderlands has deteriorated significantly over the past decade, which has hastened the demise of much of the border leisure tourism that existed before. Secondly, in tourism destinations everywhere, the act of sending physical postcards is now largely outdated and is rapidly being replaced by the use of social media. In most instances today, photographs and video clips shared with friends and family on social media have taken the place of mailing postcards (Munar \& Jacobsen, 2014). Images that were once enshrined on cardstock and posted from exotic locations are now more commonly shared in real time through mobile phone apps and social media.

In the early days, postcards were readily available in most border towns, in a wide selection of shops (Arreola, 2001). However, since the turn of the 21st century, postcards are difficult to find. Stores rarely stock them in light of their declining popularity for Americans (who traditionally have not been as prolific postcard senders as Europeans) and other foreign visitors. This is particularly the case in smaller communities like Nogales. Owing to the decrease in postcard popularity, most curios shops have stopped selling them. During the 2005-2010 visits, only a handful of souvenir stores in Tijuana and Ciudad Juárez stocked them, and only two in Nogales. The majority of postcards examined in this study were purchased from liquor stores and pharmacies (72\%), rather than traditional souvenir shops and vendors (28\%). Again, this reflects the recent shift to liquor- and pharmaceutical-based shopping as dominant activities in the border communities (Oberle \& Arreola, 2004; Cuevas-Contreras, Zizaldra-Hernández, \& Delgado-Guzmán, 2018; Adams, Snyder, \& Crooks, 2019). In fact, the reaction of shopkeepers was usually surprise and sometimes bewilderment when asked if they carried postcards. Many suggested that foreign visitors had not asked about postcards for many years, and most did not know where they could be purchased, although the author's finding postcards at pharmacies and liquor stores was based on initial recommendations by souvenir sellers. In 2018-2019, postcards were found in only two shops in Ciudad Juárez, two in Tijuana, and none in Nogales.

The tourism forms and functions of the Mexican border cities are changing. The souvenir- and restaurant-dominated tourismscapes of the past have been replaced largely by 'medical tourism' services, including pharmacies, dentists, physicians and chiropractors. There are far fewer curios shops and handicraft vendors, and the elements of vice have also begun to diminish. Many former shops where postcards would have been sold in previous years are now sitting empty.

\section{Conclusion}

The US-Mexico border has an interesting history, riddled with tourism from its very inception. Between the late nineteenth and late twentieth centuries, picture postcards played a vital role in creating the images of rowdy border towns and moulding American perceptions of what life was like south of the border, thus creating and maintaining staged stereotypical representations of Mexico at the national frontier - the only Mexican experience many Americans and Canadians ever had. As a result, a unique tourist 'Mexicoland' developed adjacent to the border, 
which was introduced and preserved in postcard images for more than a century (Arreola 2010, 2013, 2017, 2019).

To answer the first research question, because tourism grew as a result of the border, it is not surprising that the boundary itself featured prominently in early postcard images. Although the border appears less commonly in the postcards analysed here, la linea (the line) still appears on some of them. The 2000s postcards focus more on images away from the immediate border, such as street scenes, markets, cultural/tourist activities, historic monuments and buildings, and aerial panoramas. Nonetheless, all the images are connected in some way directly or indirectly to the borderline. The streets are a bustle with tourists, who visit the markets and participate in cultural activities because of the boundary situation. Aerial pictures typically show the international divide and the twin cities it bisects, revealing an interdependent tourism relationship. Churches and other buildings were constructed because of the early frontier location on the edges of the Spanish, and later, Mexican, polities. The abundance of postcards from other cities attests to the cross-boundary collective identity that is often associated with borderland locations, even on a domestic scale. And, finally, representations of the border itself bear witness to what constitutes the core appeal of borderland tourism and what local place-makers have desired to portray to the outside world.

The nature of tourism in the Mexican border towns has changed considerably during the past 35 years from self-indulgent playgrounds where people spent weekends and even entire weeks on holiday immediately south of the border. In response to the second research question, it is clear that contemporary tourism emphasises more shortterm, utilitarian day excursions for shopping, medical care, and dining/drinking, with only limited cultural enjoyment. This reorientation, together with the popularity of mobile phones and social media, has resulted in postcards becoming nearly obsolete in Mexico's northern borderlands.

\section{Editors' note:}

Unless otherwise stated, the sources of tables and figures are the authors', on the basis of their own research.

\section{References}

Adams, K., Snyder, J., Crooks, V.A. (2019). Narratives of a "dental oasis": Examining media portrayals of dental tourism in the border town of Los Algodones, Mexico. Journal of Borderlands Studies, 34(3), 325-341. https://doi.org/10.1080/08865655.2016.1267584

Albers, P.C., James, W.R. (1988). Travel photography: A methodological approach. Annals of Tourism Research, 15, 134-158.

Alam, M.R., Istiak, K. (2020). Impact of US policy uncertainty on Mexico: Evidence from linear and nonlinear tests. The Quarterly Review of Economics and Finance. 77, 355-366. https://doi.org/10.1016/j.qref.2019.12.002

Anderson, J.B., Gerber, J. (2008). Fifty years of change on the U.S.-Mexico border: Growth, development and quality of life. Austin: University of Texas Press.

Arreola, D.D. (2001). La cerca y las garitas de Ambos Nogales: a postcard landscape exploration. Journal of the Southwest, 43(4), 505-541.

Arreola, D.D. (2010). The Mexico-US borderlands through two decades. Journal of Cultural Geography, 27(3), 331-351. https://doi.org/10.1080/08873631.2010.517621

Arreola, D.D. (2013). Post cards from the Río Bravo border: Picturing the place, placing the picture, 1900s-1950s. Tucson: University of Arizona Press. 
Arreola, D.D. (2017). Post cards from the Sonora border: Visualizing place through popular lens, 1900s-1950s. Tucson: University of Arizona Press.

Arreola, D.D. (2019). Post cards from the Chihuahua border: Revisiting a pictorial past, 1900s-1950s. Tucson: University of Arizona Press.

Arreola, D.D., Burkhart, N. (2010). Photographic postcards and visual urban landscape. Urban Geography, 31(7), 885-904. https://doi.org/10.2747/0272-3638.31.7.885

Arreola, D.D., Curtis, J.R. (1993). The Mexican border cities: Landscape anatomy and place personality. Tucson: University of Arizona Press.

Arreola, D.D., Madsen, K. (1999). Variability of tourist attraction on an international boundary: Sonora, Mexico border towns. Visions in Leisure and Business, 17(4), 19-32.

Arts, A. (2019). Now let us show it to you: A multimodal discourse analysis of websites offering United States-Mexico border crossing tours. (Unpublished master's thesis). Radboud University, Nijmegen, Netherlands.

Asgary, N., de los Santos, G., Vincent, V. and Davila, V. (1997). The determinants of expenditures by Mexican visitors to the border cities of Texas. Tourism Economics, 3(4), 319-328. https://doi.org/10.1177\%2F135481669700300402

Blasco, D., Guia, J., Prats, L. (2014). Heritage tourism clusters along the borders of Mexico. Journal of Heritage Tourism, 9(1), 51-67. https://doi.org/10.1080/1743873x.2013.862537

Bowman, K.S. (1994). The border as locator and innovator of vice. Journal of Borderlands Studies, 9(1), 51-67. https://doi.org/10.1080/08865655.1994.9695451

Canally, C., Timothy, D.J. (2007). Perceived constraints to travel across the US-Mexico border among American University Students. International Journal of Tourism Research, 9(6), 423-437. https://doi.org/10.1002/jtr.614

Castaño, R., Perez, M.E., Quintanilla, C. (2010). Cross-border shopping: family narratives. Qualitative Market Research, 13(1), 45-57. https://doi.org/10.1108/13522751011013972

Castillo, D.A., Rangel Gomez, M.G., Delgado, B. (1999). Border lives: Prostitute women in Tijuana. Signs, 24(2), 388-422. https://doi.org/10.1086/495345

Cherpitel, C.J., Ye, Y., Zemore, S.E., Bond, J., Borges, G. (2015). The effect of cross-border mobility on alcohol and drug use among Mexican-American residents living at the US-Mexico border. Addictive Behaviors, 50, 28-33. https://doi.org/10.1016/j.addbeh.2015.06.008

Clancy, M. (2001). Exporting paradise: Tourism and development in Mexico. Oxford: Pergamon.

Collier, J., Collier, M. (1999). Visual anthropology: Photography as a research method. Albuquerque: University of New Mexico Press.

Cuevas, T., Blasco, D., Timothy, D.J. (2016). The Pink Store: A unique tourism enterprise at the US-Mexico border. European Journal of Tourism Research, 13, 122-131.

Cuevas Contreras, T., Zizaldra Hernández, I. (2015). A holiday celebration in a binational context: Easter experiences at the US-Mexico border. Journal of Heritage Tourism, 10(3), 296-301. https://doi.org/10.1080/1743873X.2015.1013474

Cuevas-Contreras, T., Zizaldra-Hernández, I. and Delgado-Guzmán, J.A. (2018). Desarrollando un cluster de turismo medico: Caso de Ciudad Juárez, Chihuahua, México. In S.A. Gómez, M.R Llamas Paz and R.M. Jiménez (eds) Turismo Médico en el Norte de México: Oportunidades, Retos, Dilemas y Políticas Públicas, pp. 45-68. San Luis Río Colorado: Universidad Estatal de Sonora.

Curtis, J.R. (1993). Central business districts of the two Laredos. Geographical Review, 83(1), 54-65. https://doi.org/10.2307/215380

Curtis, J.R., Arreola, D.D. (1989). Through Gringo eyes: tourist districts in the Mexican border cities as other-directed places. North American Culture, 5(2), 19-32. 
Curtis, J.R., Arreola, D.D. (1991). Zonas de tolerancia on the northern Mexican border. Geographical Review, 81(3), 333-346. Zonas de tolerancia on the northern Mexican border. Geographical Review, 81(3), 333-346

Dillman, C.D. (1970). Recent developments in Mexico's national border program. Professional Geographer, 22(5), 243-247. https://doi.org/10.1111/j.0033-0124.1970.00243.x

Edelheim, J.R. (2007). Hidden messages: a polysemic reading of tourist brochures. Journal of Vacation Marketing, 13(1), 5-17. https://doi.org/10.1177/1356766706071202

Fleming, W.C. (2014). Icons, itinerary, and identity: Associations of boundary and mobility within the contemporary US passport. Mobilities, 9(1), 42-62. https://doi.org/10.1080/17450101.2013.800760

Frejomil, E.P., Sanchez-Crispin, A., Lopez, A.L. (1997). Situación geográfico-económica del turismo en el extreme norte de América Latina: El corridor Tijuana-Rosarito-Ensenada. Revista de Geografía Norte Grande, 24, 257-261.

Fullerton, T.M., Walke, A.G. (2019). Cross-border shopping and employment patterns in the southwestern United States. Journal of International Commerce, Economics and Policy, 10(3), 195. https://doi.org/10.1142/s1793993319500157

Ganster, P., Collins, K. (2017). Binational cooperation and twinning: A view from the US-Mexican border, San Diego, California, and Tijuana, Baja California. Journal of Borderlands Studies, 32(4), 497-511. https://doi.org/10.1080/08865655.2016.1198582

Ganster, P., Lorey, D.E. (2008). US-Mexican border into the twenty-first century. Lanham, MD: Rowman \& Littlefield.

Garrod, B. (2009). Understanding the relationship between tourism destination imagery and tourist photography. Journal of Travel Research, 47(3), 346-358. https://doi.org/10.1177/0047287508322785

Garrod, B., Kosowska, A. (2012). Destination image consistency and dissonance: A content analysis of Goa's destination image in brochures and guidebooks. Tourism Analysis, 17(2), 167-180. https://doi.org/10.3727/108354212×13388995267823

Gelbman, A. (2008). Border tourism in Israel: conflict, peace, fear and hope. Tourism Geographies, 10(2), 193-213. https://doi.org/10.1080/14616680802000022

Gelbman, A. (2019). Tourism, peace and global stability. In D.J. Timothy (ed.) Handbook of globalisation and tourism (pp. 149-160). Cheltenham: Edward Elgar. https://doi.org/10.4337/9781786431295.00022

Gelbman, A., Timothy, D.J. (2010). From hostile boundaries to tourist attractions. Current Issues in Tourism, 13(3), 239-259. https://doi.org/10.1080/13683500903033278

Gibbons, J.D., Fish, M. (1987). Market sensitivity of U.S. and Mexican border travel. Journal of Travel Research, 26(1), 2-6. https://doi.org/10.1177/004728758702600101

González, E.D., König, G.G. (2016). An analysis of Mexican consumers' purchases in the United States based on household spending. Estudios Fronterizos, 17(33), 115-140.

https://doi.org/10.21670/ref.2016.33.a06

Gravelle, T.B. (2018). Politics, time, space, and attitudes toward US-Mexico border security. Political Geography, 65, 107-116. https://doi.org/10.1016/j.polgeo.2018.05.012

Hansen, N. (1982). Economic growth patterns in the Texas borderlands. Natural Resources Journal, 22(4), 805-821.

Hanson, G.H. (1996). U.S.-Mexico integration and regional economies: Evidence from border-city pairs. Cambridge, MA: National Bureau of Economic Research. https://doi.org/10.3386/w5425

Herzog, L.A. (2003). Global Tijuana: The seven ecologies of the border. In M. Dear and G. Leclerc (eds) Postborder city: Cultural spaces of Bajalta California, pp. 119-142. New York: Routledge.

Human, B. (1999). Kodachrome icons: photography, place and the theft of identity. International Journal of Contemporary Hospitality Management, 11(2/3), 80-84.

https://doi.org/10.1108/09596119910250733

Jenkins, O.H. (2003). Photography and travel brochures: the circle of representation. Tourism Geographies, 5(3), 305-328. https://doi.org/10.1080/14616680309715 
Lange, J.E., Voas, R.B., Johnson, M.B. (2002). South of the border: A legal haven for underage drinking. Addiction, 97, 1195-1203. https://doi.org/10.1046/j.1360-0443.2002.00182.x

Lucero, H.M. (2003). Peopling Baja California. In M. Dear and G. Leclerc Eds.), Postborder city: Cultural spaces of Bajalta California (pp. 83-115), New York: Routledge.

Luna, S. (2018). Affective atmospheres of terror on the Mexico-US border: Rumors of violence in Reynosa's prostitution zone. Cultural Anthropology, 33(1), 58-84. https://doi.org/10.14506/ca33.1.03

Mamiya, C.J. (1992). Greetings from paradise: The representation of Hawaiian culture in postcards. Journal of Communication Inquiry, 16(2), 86-101. https://doi.org/10.1177/019685999201600207

Markwick, M. (2001). Postcards from Malta: Image, consumption, context. Annals of Tourism Research, 28, 417-438. https://doi.org/10.1016/s0160-7383(00)00049-9

Martínez, O.J. (2015). Mexico's Uneven Development: The Geographical and Historical Context of Inequality. New York: Routledge. https://doi.org/10.4324/9781315732657

Martínez, O.J. (2018). Ciudad Juárez: Saga of a Legendary Border City. Tucson: University of Arizona Press. https://doi.org/10.2307/j.ctt1zxsmcr

Martínez Almanza, M.T., Guía Julve, J., Morales Muñoz, S.A., Esparza Santillana, M.A. (2019). Border medical tourism: the Ciudad Juárez medical product. Anatolia, 30(2), 258-266. https://doi.org/10.1080/13032917.2018.1519216

Mayes, R. (2010). Doing cultural work: local postcard production and place identity in a rural shire. Journal of Rural Studies, 26(1), 1-11. https://doi.org/10.1016/j.jrurstud.2009.06.002

Milman, A. (2011). The symbolic role of postcards in representing a destination image: The case of Alanya, Turkey. International Journal of Hospitality and Tourism Administration, 12(2), 144-173. https://doi.org/10.1080/15256480.2011.564495

Milman, A. (2012). Postcards as representation of a destination image: The case of Berlin. Journal of Vacation Marketing, 18(2), 157-170. https://doi.org/10.1177/1356766711435975

Moker, M. (2010). Fodor's San Diego 2010, with North County and Tijuana. New York: Random House.

Morgan, N., Pritchard, A. (1998). Tourism promotion and power: Creating images, creating identities. Chichester: Wiley.

Munar, A.M., Jacobsen, J.K.S. (2014). Motivations for sharing tourism experiences through social media. Tourism Management, 43, 46-54. https://doi.org/10.1016/j.tourman.2014.01.012

Oberle, A.P., Arreola, D.D. (2004). Mexican medical border towns: A case study of Algodones, Baja California. Journal of Borderlands Studies, 19(2), 27-44. https://doi.org/10.1080/08865655.2004.9695625

Paasi, A., Raivo, P. (1998). Boundaries as barriers and promoters: constructing the tourist landscapes of Finnish Karelia. Visions in Leisure and Business, 17(3), 30-45.

Pearson, C. (2016). Canines and contraband: Dogs, nonhuman agency and the making of the FrancoBelgian border during the French Third Republic. Journal of Historical Geography, 54, 50-62. https://doi.org/10.1016/j.jhg.2016.07.005

Prock, J. (1983). The peso devaluations and their effect on Texas border economies. Inter-American Economic Affairs, 37(3), 83-92.

Prokkola, E-K. (2010). Borders in tourism: the transformation of the Swedish-Finnish border landscape. Current Issues in Tourism, 13(3), 223-238. https://doi.org/10.1080/13683500902990528

Ramos, K., Cuamea, O. (2019). Predictors of satisfaction for American aesthetic tourism at the Mexican border. Advances in Hospitality and Tourism Research, 7(1), 38-56.

Shirk, D., Webber, A. (2004). Slavery without borders: human trafficking in the US-Mexico context. Hemisphere Focus, 12(5), 1-5.

Stoffelen, A. (2018). Tourism trails as tools for cross-border integration: A best practice case study of the Vennbahn cycling route. Annals of Tourism Research, 73, 91-102.

https://doi.org/10.1016/j.annals.2018.09.008 
Sullivan, P., Bonn, M.A., Bhardwaj, V., DuPont, A. (2012). Mexican national cross-border shopping: Exploration of retail tourism. Journal of Retailing and Consumer Services, 19(6), 596-604. https://doi.org/10.1016/j.jretconser.2012.07.005

Swanson, K.K., Timothy, D.J. (2012). Souvenirs: Icons of meaning, commercialization, and commoditization. Tourism Management, 33(3), 489-499. https://doi.org/10.1016/j.tourman.2011.10.007

Symes, C. (2019). Something to write home about: A 'textography'of contemporary postcards. Annals of Leisure Research, 22(5), 642-660. https://doi.org/10.1080/11745398.2019.1567358

Tiano, S., Murphy-Aguilar, M. (Eds.). (2016). Borderline slavery: Mexico, United States, and the human trade. London: Routledge. https://www.taylorfrancis.com/terms-and-conditions

Timothy, D.J. (1995). Political boundaries and tourism: Borders as tourist attractions. Tourism Management, 16(7), 525-532. https://doi.org/10.1016/0261-5177(95)00070-5

Timothy, D.J. (2001). Tourism and political boundaries. London: Routledge. https://doi.org/10.4324/9780203214480

Timothy, D.J., Butler, R.W. (1995). Cross-border shopping: A North American perspective. Annals of Tourism Research, 22(1), 16-34. https://doi.org/10.4324/9780203098165

Timothy, D.J., Canally, C. (2008). The role of the US-Mexico border as a destination: Student traveler perceptions. Tourism Analysis, 13(3), 259-269. https://doi.org/10.3727/108354208786094834

Toudert, D., Bringas-Rábago, N.L. (2018). Exploring the impact of destination attachment on the intentional behaviour of the US visitors familiarized with Baja California, Mexico. Current Issues in Tourism, 21(7), 805-820. https://doi.org/10.1080/13683500.2015.1110566

Turner, L. (2008). Cross-border dental care: 'Dental tourism' and patient mobility. British Dental Journal, 204(10), 553-554. https://doi.org/10.1038/sj.bdj.2008.403

Vanderwood, P.J., Samponaro, F.N. (1988). Border fury: A picture postcard record of Mexico's revolution and U.S. war preparedness, 1910-1917. Albuquerque: University of New Mexico Press.

Vaquera-Vásques, S. (2012). Postcards from the border. In J. Kun and F. Montezemolo (Eds.), Tijuana dreaming: Life and art at the global border (pp. 117-135). Durham, NC: Duke University Press.

Weaver, T. (2001). Time, space, and articulation in the economic development of the U.S.-Mexico border region from 1940 to 2000. Human Organization, 60(2), 105-120. https://doi.org/10.17730/humo.60.2.dt8w7cg0pjr5xvxg

Weigl, A.B. (2000). United States postcards of the Mexican Revolution: The agenda of the corpse. (Unpublished Master's thesis), University of California, Riverside.

Więckowski, M. (2010). Tourism development in the borderlands of Poland. Geographia Polonica, 83(2), 67-81. https://doi.org/10.7163/gpol.2010.2.5

Więckowski, M. (2013). Eco-frontier in the mountainous borderlands of Central Europe: The case of Polish border parks. Journal of Alpine Research / Revue de géographie alpine, 101(2), 1-13.

https://doi.org/10.4000/rga.2107

Więckowski, M. (2018). From periphery and the doubled national trails to the cross-border thematic trails: New cross-border tourism in Poland. In D.K. Müller, M. Więckowski (Eds.) Tourism in transitions: Recovering decline, managing change (pp. 173-186). Cham, Switzerland: Springer. https://doi.org/10.1007/978-3-319-64325-0_10

Yüksel, A., Akgül, O. (2007). Postcards as affective image makers: an idol agent in destination marketing. Tourism Management, 28(3), 714-725. https://doi.org/10.1016/j.tourman.2006.04.026 